\section{CERN's LEP makes its first zeds \\ London}

THE new Large Electron-Positron collider (LEP) at CERN, the European Laboratory for Particle Physics, has produced its first $Z^{0}$ particles only four weeks after being brought into operation. The first one was spotted by the OPAL collaboration at midnight on Sunday 13 August, just 16 minutes into the first experimental run on the machine. Another four were seen during the next two hours.

The $Z^{0}$ was first observed in collisions between protons and antiprotons at CERN in 1983, earning the Nobel Prize for Simon van der Meer and Carlo Rubbia, now CERN's director. By producing and studying $Z^{0}$ s in quantity, physicists should be able to resolve many of the uncertainties in the standard model of the fundamental forces. The Stanford Linear Collider (SLC) in California, an upgraded version of an earlier electron accelerator, has been making $Z^{0}$ s since April this year, but LEP is expected to outperform SLC significantly. The $27-\mathrm{km}$ circular machine should produce about a million $Z^{0} s$ a year, whereas SLC, although it is still not running fully to

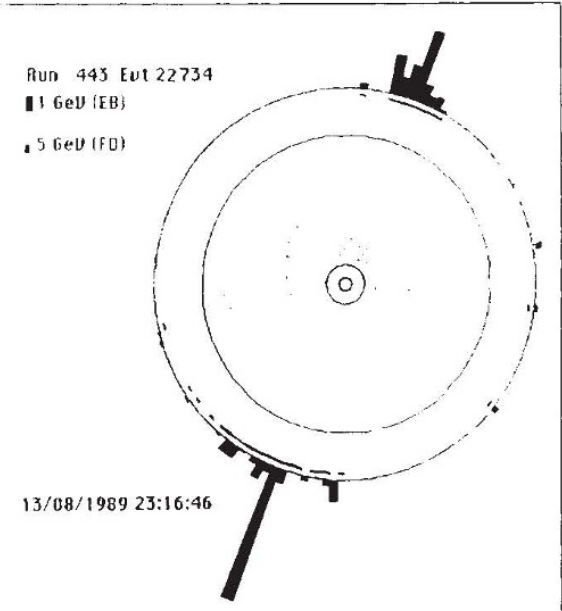

The first $Z^{0}$ : back-to-back high-energy jets detected by OPAL's lead glass calorimeter. Total energy available from the collisions was $91 \mathrm{GeV}$, about the mass of the $Z^{0}$. The energy deposited in the jets is proportional to the length of the bars. (Courtesy David J. Miller.)

design specification, has made 240 in its first four months of operation.

The detection rate at LEP should soon increase by a factor of at least 400 because the beams are now running at only onetenth of their design current and because the quadrupole focusing magnets, which squeeze the beams at the collision point, are not yet in use. David J. Miller, a member of the OPAL collaboration, says that the four weeks taken from passing the first beams to seeing the first $Z^{0} s$ is a remarkably short time in accelerator physics - possibly a record.

Roland Pease

\title{
Controversy persists
}

\section{London}

LASZLO Udvari, Hungary's commissioner for the controversial Gabcikovo-Nagymaros hydroelectric project, last week denied Austrian press reports that construction work at Nagymaros will resume in November. The Austrians have a big financial investment in the Hungarian end of the project, which, if the Nagymaros dam is completed, will be repaid in electricity. Last May, following several years' campaigning by environmental groups in Hungary, the Hungarian government announced a two-month moratorium on construction at Nagymaros. This moratorium expired in July, but work at Nagymaros is still continuing only at the minimum level needed to maintain the temporary coffer-dam around the uncompleted structures. Now, an expert commission from the Hungarian Academy of Sciences is advocating a moratorium of several years to allow a "realistic" assessment to be made of the environmental aspects of the problem.

Previous Hungarian official reports have concluded that although the scheme was a planning error, it would now be too costly, both financially and politically, to cancel, and that with sufficient additional investment the environmental damage could be minimized. The latest academy report, however, says that previous surveys have failed to pay sufficient attention to the protection of water quality, although 3 million Hungarians (out of a population of 10.5 million) drink the filtered water of the Danube.

But cancelling the Nagymaros dam would not save Hungary's water supply, although it would reduce the damage. The main problem, the Hungarian experts say, will be the Gabcikovo dam, upstream in Czechoslovakia. And, although individual experts from the Slovak Academy of Sciences are now beginning to voice their doubts, the Prague government remains firmly committed to its side of the joint project. Not only does the Czechoslovak economy need the electricity that Gabcikovo will produce, but the scheme, originally hailed as a triumph of Socialist cooperation, continues to appeal to a regime committed to the principles of the Brezhnev era, including its sponsorship of grandiose 'prestige' engineering projects.

The Czechoslovak government is therefore doing all it can to persuade the Hungarians to complete their side of the deal. At a bilateral conference on the dams in Budapest last month, the Czechoslovak team refused to take seriously Hungarian arguments that the Nagymaros dam lies on a tectonic fault, with the consequent risk from earthquakes. Czechoslovak experts, said Dr Ludvik Vanel, a corres- ponding member of the Czechoslovak Academy of Sciences, consider that the tectonic disturbances recorded at the site are "quite common" and that all that is needed is a "network of technical stations" monitoring the two dams. The Czechoslovak team particularly objected to the presence in the Hungarian delegation of representatives of 'alternative' environmental groups, who, they claimed, were "inadequately informed". Yet, said Hungarian Academician Pal Stfanovits, the major objections to the dam are based on work carried out by the Hungarian National Geological Institute over almost 10 years, which was ignored by both the Czechoslovak and the Hungarian designers.

The Budapest conference resolved nothing. The Prague politicians and the Austrian investors continue to scold the Hungarians on treaty and contractual obligations and to press their claims for compensation. To this, Commissioner Udvari has replied that if the ecological and natural risks apply not only to the Hungarians but also to the inhabitants of Czechoslovakia and Austria (as in the case of seismic risk), then there can be "no justification" for compensation claims.

But even if the Hungarians do get the "several years" moratorium they are now seeking, further construction work will be needed at Nagymaros in the meantime. For, according to experts, the temporary coffer-dam around the site will not endure the rigours of more than two or three Danube winters.

Vera Rich

ATMOSPHERIC SCIENCE —_ _ _ _

\section{New German} \section{programme}

Munich

ENCOURAGED by a parliamentary Enquete commission established last year "for the protection of the earth's atmosphere", Research Minister Heinz Riesenhuber last week announced an initiative consolidating West German efforts in research into atmospheric science and climate change into a new "priority programme". West Germany will invest annually, beginning in 1990, DM 10-15 million of new money into projects meant to provide more data for politicians who want to protect the environment.

In addition to supporting the "Climate Computing Centre" in Hamburg, which bought a Cray-2 supercomputer last October, the new programme is expected to focus on the roll of the ocean as a possible sink for man-made carbon dioxide. The role played by steam, clouds and aerosols in global warming will also be studied.

Steven Dickman 